\title{
Ornis Svecica moulting into its new plumage
}

\section{Ornis Svecica i ny fjäderdräkt}

\author{
Martin Stervander ${ }^{1}$ (1) \& Jonas Waldenström² \\ ${ }^{1}$ Institute of Ecology and Evolution, University of Oregon, Eugene OR 97403, USA | martin@stervander.com ² Department \\ of Biology and Environmental Science, Linnaeus University, 39182 Kalmar, Sweden | jonas.waldenstrom@Inu.se
}

AT THE START of the new decade, Ornis Svecica is now entering its 30 th year as an ornithological journal. It is a year of change for the journal, perhaps most evident in the transition that started last year with Ornis Svecica moving from a printed journal to an online journal (Stervander \& Svensson 2019). Being digital is a necessary step in today's publishing landscape and we are happy that we alongside this change also publish all papers as open access, making research available for everyone that is interested.

Another major change is that Professor Sören Svensson is stepping down after 29 years as Editor-in-Chief. His role for Ornis Svecica-and indeed for BirdLife Sweden and Swedish ornithology at large-has been profound. During this time the field of ornithology has both widened and specialized. The toolbox of the modern ornithologist now includes molecular biology techniques, advanced miniaturized telemetry loggers, and large-scale weather radar data. But ornithology is still at heart based on careful observation of the natural world, through surveys, ringing and migration studies. The editorial board wishes to express heartfelt thanks to Sören, for his significant contributions.
New Editor-in-Chief is Jonas Waldenström, professor at Linnaeus University in Kalmar, Sweden. Although new in this role, Jonas has been an editor for Ornis Svecica for 15 years and chairman of Ottenby Bird Observatory for over a decade. His very first paper was published in Ornis Svecica, in 2000, on how plumage-based sexing of Common Whitethroats Sylvia communis held up against molecular sexing (spoiler: not very well; Waldenström \& Ottosson 2000). As new EiC it is always tempting to clear a new path or make things differently. However, apart from the necessary step of providing an indexed modern publishing platform, the values at core of the journal are the same today as they were 30 years ago. Ornis Svecica should act as bridge between amateur ornithologists and professional ornithologists, and be a go-to journal for descriptive ornithological research.

As of this year, we are also very proud to welcome no less than five new editors of Ornis Svecica:

CECILIA NILSSON is a postdoctoral research fellow at University of Copenhagen and does research on bird migration and flight behaviour, in particular by using radar technologies at local and continental scales. 
ANDREAS NORD is a researcher at Lund University, where he focuses on ecophysiology in birds, for example by exploring the effect of the ambient temperature on energy expenditure.

MARTINA KADIN is a postdoctoral research fellow at the Swedish Museum of Natural History, where she studies the synchrony in survival of seabirds at different spatial and ecological scales.

JONAS HENTATI SUNDBERG is an aSSOciate senior lecturer at the Swedish University of Agricultural Sciences, where he combines field studies with novel technologies to primarily study seabird ecology and effects of fisheries management.

SISSEL SJÖBERG is a postdoctoral research fellow at the University of Copenhagen and studies migratory behaviour and strategies in birds using a variety of tracking devices.

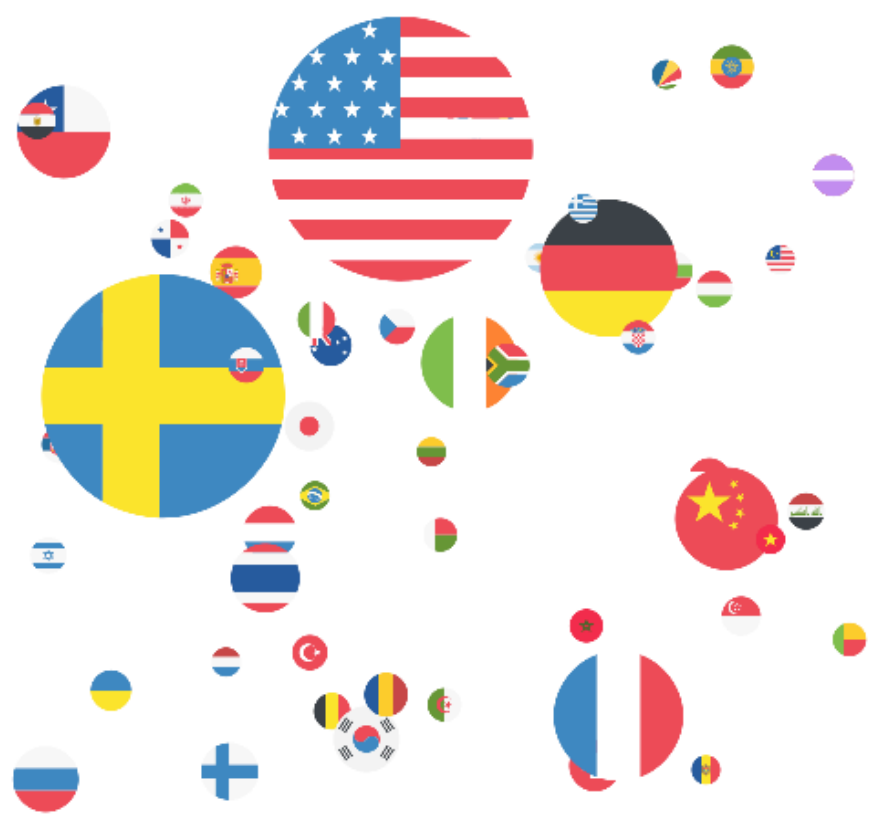

FIGURE 1. Graphic representation of the geographic origin of the 8,231 site home page visits from 60 countries during 2019. The size of the flag is scaled to number of visits, although not proportionally, as countries with few visits would not be visible. - Visualisering av det geografiska ursprunget för de 8231 besöken på sajtens förstasida från 60 länder under 2019. Flaggans storlek är skalad utifrån antal besök, men inte helt proportionerligt, då länder med få besök inte skulle vara synliga.
You can read more about our editorial board at the journal site.

One of the reasons for Ornis Svecica to transition to continuous online publishing was to increase our reach and readership. We could not have predicted how well this would turn out, but for 2019-following our launch in mid-May-the start page of the journal site has received over 8,000 visits from 60 countries spread over all inhabited continents of the globe (Figure 1). Perhaps even more gratifying is that most of those visits have resulted in views of individual journal article pages, with an average of 540 (top paper 1,042) for last year's new papers, and 77 for back-published papers. Most of those views also resulted in a download of the paper's pdf file, with an average of 318 (59\%; top paper 688 ) for last year's new papers, and $64(84 \%)$ for backpublished papers. That sums up to a total of 6,707 article views and 4,538 pdf downloads. Additional reach was achieved during the autumn of 2019, when Ornis Svecica entered a partnership with EBSCO, a company that provides contents of academic journals to many university and research libraries around the world.

During 2019, Ornis Svecica published five research papers and two short reports, with a total of 83 pages. This is lower than usual, but mainly explained by one third of the year spent preparing the transition in publishing. We are happy to note an increased rate of submissions lately, both from authors who have previously published with Ornis Svecica, and authors new to the journal. Several manuscript are currently under review and in the production pipeline, and we are happy to inaugurate Volume 30 with a paper by long-standing Ornis Svecica author Hans Källander. He has compiled observations from eight visits between 1991 and 2018 to Greek lakes, at which he has observed the interspecific associations between foraging Dalmatian Pelicans Pelecanus crispus and Great Cormorants Phalacrocorax carbo. Read more in Källander (2020) about their at times mutually beneficial, and other times thieving, behaviour! We are also grateful to the English nature 
photographer Daniel Trim, who has graced us with an artistic photo for the cover of Volume 30, depicting the pelicans and cormorants at Lake Kerkini, which is one of the study sites of Källander (2020).

We welcome you to enjoy Ornis Svecica's publication of avian research by academics and amateur ornithologists alike. In addition to publishing new contributions, we will continue our efforts to publish the entire body of previous volumes on the journal site os.birdlife.se. If you want to make sure not to miss any new contributions, register as reader there, and/or follow us on social media such as Twitter and Facebook, where we can be found under the handle @OrnisSvecica. We also appreciate your help in spreading the word to new potential readers and authors! If you have material that you think may be suitable for the journal, do not hesitate to make a submission via our site, or-especially if you are inexperienced with scientific writing-get in touch with the editors to ask for advice or feedback.

\section{References}

Källander H. 2020. The kleptoparasitic and commensal association of Dalmatian Pelicans Pelecanus crispus with Great Cormorants Phalacrocorax carbo. Ornis Svecica 30: 4-11. https://doi.org/10.34080/ os.v30.20265

Stervander M \& Svensson S. 2019. Ornis Svecica fledges into the modern publishing landscape. Ornis Svecica 29: 1-4. https://doi. org/10.34080/os.v29.19598

Waldenström J \& Ottosson U. 20oo. The accuracy of field sex determination in the Common Whitethroat Sylvia c. communis. Ornis Svecica 10: 67-70. https://doi.org/10.34080/os.v10.20574

\section{Svensk version}

För svenska ornitologer är Ornis Svecica en gammal kär bekantskap och en inarbetad tidskrift för faggelforskning. Sedan starten för 30 år sedan har Ornis Svecica utgjort en länk mellan amatörforskare och universiteten och hjälpt till att publicera en lång rad uppsatser om fågelfaunan i Sverige och annorstädes. Trettio år är en ansenlig tid för en tidskrift och det är med stolthet som redaktionen kan se tillbaka på de år som gått. För 2020 är inte bara starten på ett nytt decennium, utan också ett år då flera förändringsprocesser slår igenom för tidskriften.

Den första förändringen är själva publiceringsformen, som nu är helt digital. Processen inleddes redan ifjol och nu är pappersformen helt borta. Att publicera digitalt är idag standard för vetenskapliga tidskrifter. Fördelen är uppenbar: allt finns ett knapptryck bort, tillgängligt för alla som är intresserade av fåglar. Nackdelar finns också, kanske främst $i$ att behålla känslan av en tidskrift - ni vet, att öppna brevlådan och hitta en splitterny Ornis Svecica tillsammans med räkningarna och ICA-kuriren. Vi hoppas att ni - våra trogna läsare - fortsätter att läsa Ornis Svecica, och att vi samtidigt kan locka nya läsare med hjälp av de nya formerna för publicering som digitaliseringen erbjuder.

En titt på fjolårets besöksstatistik för tidskriftens webbplats visar att vi är på rätt väg, med över 8000 besök från 60 länder (figur 1) sedan lanseringen i maj. Totalt visades Ornis Svecica-uppsatser inte mindre än 6707 gånger, med 4538 nedladdningar av pdf-filer, och i snitt 540 visningar för nya uppsatser (toppnotering på 1 042). Under 2019 ingick tidskriften också ett partnerskap med EBSCO, ett företag som tillhandahåller akademiska tidskrifters innehåll för många universitetsbibliotek världen över.

En annan stor förändring är att Sören Svensson slutar som huvudredaktör för tidskriften. Sören har varit med sedan starten och har under 29 år varit den som, med fast och varsam hand, lett Ornis Svecica framåt. Hans insats för amatörforskningen och ornitologin i Sverige är avsevärda; förutom Ornis Svecica var han under en lång rad år även ordförande för Sveriges Ornitologiska Förening (nuvarande BirdLife Sverige) och drev Svensk faggeltaxering från Lunds universitet. Redaktionen tackar Sören för en fantastisk prestation genom dessa år och hoppas att vi kan förvalta arvet framåt.

Ny huvudredaktör sedan årsskiftet är Jonas Waldenström, verksam vid Linnéuniversitetet i Kalmar, där han bedriver forskning kring făglar som bärare av olika sjukdomsbringande mikroorganismer, inte minst influensavirus hos änder. Dessutom har inte mindre än fem nya redaktörer knutits till redaktionen: Cecilia Nilsson, 
postdoktoral forskare vid Köpenhamns universitet, som studerar fågelflyttning med hjälp av radar; Andreas Nord, forskare vid Lunds universitet, som studerar faglars fysiologi i deras naturliga miljö; Martina Kadin, postdoktoral forskare vid Naturhistoriska riksmuseet, som studerar havsfaggelekologi; Jonas Hentati-Sundberg, biträdande universitetslektor vid Sveriges landsbruksuniversitet i Lysekil, som studerar havsfågelekologi och fiskeriförvaltning; och Sissel Sjöberg, postdoktoral forskare vid Köpenhamns universitet, som studerar flyttfäglar beteenden och strategier.

Under 2019 publicerade Ornis Svecica fem uppsatser samt två korta rapporter om totalt 83 sidor. Det är lägre siffror än vanligt, men en tredjedel av året tillbringades med förändringsarbete inför den digitala publiceringen. Vi har med glädje noterat en ökad manustillströmning från både återkommande och nya författare. Flera manuskript är under granskning eller produktion och vi är nöjda med att inleda årgång 30 med en uppsats av den mångårige Ornis Svecica-författaren Hans Källander. Han har analyserat observationer gjorda under åtta besök i Grekland mellan 1991 och 2018, där han iakt- tagit samspelet mellan krushuvade pelikaner Pelecanus crispus och storskarvar Phalacrocorax carbo som fangar fisk - beteenden som tidvis är till båda arters gagn och tidvis är rent tjuveri (Källander 2020). Vi är tacksamma för att den engelske naturfotografen Daniel Trim har lånat oss sitt konstnärliga foto av pelikaner och skarvar i full fart, vilket pryder framsidan för årgång 30 .

Om du vill vara helt säker på att inte missa de kommande bidragen till Ornis Svecica rekommenderar vi dig att registrera dig som läsare på tidskriftens webbplats os.birdlife.se, där vi under året också kommer att fortsätta tillgängliggöra Ornis Svecicas äldre uppsatser. Du är också varmt välkommen att följa oss i sociala medier, därdu hittar oss som @OrnisSvecica på Twitter och Facebook. Berätta gärna för dina faggelintresserade vänner om oss, så kan fler av både läsare och författare hitta hit! Kanske har du också ett material som skulle passa Ornis Svecica? I så fall kan du skicka in ditt bidrag direkt på webbplatsen, eller - i synnerhet om du aldrig skrivit vetenskapligt tidigare - ta kontakt med redaktionen för synpunkter och råd.

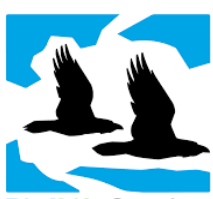

Birdlife Sverige

Ornis Svecica (ISSN 2003-2633) is an open access, peer-reviewed scientific journal published in English and Swedish by BirdLife Sweden. It covers all aspects of ornithology, and welcomes contributions from scientists as well as non-professional ornithologists. Accepted articles are published at no charge to the authors. Read papers or make a submission at os.birdlife.se.

Ornis Svecica (ISSN 2003-2633) är en fritt tillgänglig granskad vetenskaplig tidskrift som ges ut på svenska och engelska av BirdLife Sverige. Den täcker ornitologins alla områden och välkomnar bidrag från såväl forskare som icke-professionella ornitologer. Accepterade uppsatser publiceras utan kostnad för författarna. Läs uppsatser eller skicka in ditt bidrag på os.birdlife.se. 